\title{
ПРАВОВЫЕ И НРАВСТВЕННЫЕ АСПЕКТЫ \\ ИСКУССТВЕННОГО ПРЕРЫВАНИЯ БЕРЕМЕННОСТИ И \\ ПЛАНИРОВАНИЯ СЕМЬИ В РОССИИ: РЕЗУЛЬТАТЫ \\ ЭКСПЕРТНОГО ОПРОСА, ПРОВЕДЕННОГО В 1996 ГОДУ
}

\author{
ВЛАДИМИР БОРИСОВ, АЛЕКСАНДР СИНЕЛЬНИКОВ, \\ ВЛАДИМИР АРХАНГЕЛЬСКИЙ
}

\begin{abstract}
В статье представлены результаты опроса экспертов, проведенного в январе-феврале 1996 г. с цуелью выявления мнений спещиалистов по ряду принципиальных вопросов, касающихся контроля рождаемости в России. Данное исследование было частью исследовательского проекта «Планирование семьи и политика общественного здравоохранения в России: переход от аборта к контрацепции в меняющемся обществе», выполнявшегося Институтом международных исследований семьи (Москва) в 1995-1997 г2. Всего было опрошено 89 экспертов, представлявших научные круги исследователей из различных областей знания (география, демография, история, психология, медицина, философия, экономика), организаторов здравоохранения и практикующих врачей, депутатов Государственной думьl, представителей федеральных и региональных органов исполнительной власти и священников. Программа опроса охватывала вопросы легитимности и моральной приемлемости аборта, оценку действующего законодательства об искусственном прерывании беременности, оценку допустимости людьми регулирования репродуктивной функции и наиболее приемлемых способов контроля рождаемости в контексте тенденций рождаемости в стране, оценку деятельности общественных организаций, выступающих за ограничение и запрещчение аборта по желанию женщин и возможных последствий изменения законодательства по отношению $\kappa$ аборту $и$ планированию семьи. Подавляюшее большинство опрошенных экспертов поддержали безусловное право женщин решать судьбу своей беременности. Законодательный запрет абортов и ограничение права женщин на прерывание беременности по их желанию, по мнению экспертов, не решил бы проблемы низкой рождаемости и мог бы иметь только отрицательные последствия с точки зрения повышения уровня криминогенности в стране и ухудшения состояния здоровья женского населения. Спустя четверть века вопросы, затронутые в исследовании середины 1990-х, остаются по-прежнему актуальными.
\end{abstract}

Ключевые слова: опрос экспертов, рождаемость, искусственное прерывание беременности, аборты, планирование семьи, контрацепџия, репродуктивное здоровье, законодательство об аборте.

ВЛАДИМИР АЛЕКСАНДРОВИЧ БОРИСОВ, УМЕР В 2005 Г. НА МОМЕНТ НАПИСАНИЯ СТАТЬИ РАБОТАЛ НА СОЦИОЛОГИЧЕСКОМ ФАКУЛЬТЕТЕ МГУ ИМ. М.В. ЛОМОНОСОВА И В ГОСУДАРСТВЕННОМ ПЕДАГОГИЧЕСКОМ УНИВЕРСИТЕТЕ.

АЛЕКСАНДР БОРИСОВИЧ СИНЕЛЬНИКОВ (sinalexander@yandex.ru), МОСКОВСКИЙ ГОСУДАРСТВЕННЫЙ УНИВЕРСИТЕТ ИМЕНИ М.В. ЛОМОНОСОВА, РОССИЯ.

ВЛАДИМИР НИКОЛАЕВИч АРХАНГЕЛЬСКИЙ (archangelsky@yandex.ru), МОСКОВСКИЙ ГОСУДАРСТВЕННЫЙ УНИВЕРСИТЕТ ИМЕНИ М.В. ЛОМОНОСОВА, РОССИЯ.

СТАТЬЯ ПОСТУПИЛА В РЕДАКЦИЮ В ИЮНЕ 2021 Г. 


\section{ПРЕДИСЛОВИЕ (ОТ РЕДАКЦИИ)}

Данное исследование было выполнено в рамках проекта: «Планирование семьи и политика общественного здравоохранения в России: переход от аборта к контрацепции в меняющемся обществе», начатому директором и основателем Института международных исследований семьи, кандидатом медицинских наук Андреем Анатольевичем Поповым ${ }^{1}$. Частью проекта было изучение мнений специалистов различных отраслей науки и должностных лиц, представляющих разные сферы жизни общества, по ряду моральных, правовых и медицинских аспектов контроля рождаемости и планирования семьи в России. Эта часть проекта не была завершена к моменту трагической смерти руководителя А.А. Попова в апреле 1995 г. Авторы постарались реализовать задуманное А.А. Поповым исследование, результаты которого представлены ниже. Статья была написана в 1996 г., непосредственно после завершения исследования, и в наиболее полной мере отражает полученные результаты ${ }^{2}$

С тех пор прошло более двух десятков лет, существенным образом изменились социально-демографическая обстановка и политический контекст в стране. Однако дебаты по вопросам абортов и планирования семьи по-прежнему остаются среди наиболее острых как в экспертном сообществе, так и в широких кругах акторов, формирующих общественное мнение. В развитие данной темы было опубликовано множество научных работ в российских изданиях и за рубежом (см., например: Вишневский и др. 2017; Кочергина 2017; Темкина 2013; Сакевич, Денисов 2019; Denisov et al. 2012; Philipov et al. 2004; Troitskaia et al. 2009). Тем не менее, мы решили вернуться к исследованию 1996 г., поскольку фактографические материалы опроса экспертов, представленные ниже, не только характеризуют ситуацию, сложившуюся к началу 1990-х годов в России, и тем самым обеспечивают информационное пространство для сравнительных исследований произошедших изменений в России в постсоветский период ее истории, но и дают представление о различных мнениях опытных и квалифицированных людей, голоса которых дошли до нас из прошлого, оставаясь на удивление актуальными, к которым не вредно прислушаться и сегодня, принимая политические решения, затрагивающие интересы миллионов россиян.

\section{АБОРТЫ И КОНТРАЦЕПЦИЯ ПО ДАННЫМ ОФИЦИАЛЬНОЙ СТАТИСТИКИ}

Прежде чем перейти к изложению результатов проведенного исследования, представляется необходимым вкратце обрисовать современные тенденции планирования семьи в России.

Под планированием семьи нами понимается деятельность семьи (или индивида), направленная на достижение желаемого числа детей в желательные сроки. Если ограничить это понятие только вопросами регулирования деторождения (оставив в стороне вопросы бесплодия и адопции, т.е. усыновления детей), то такое регулирование на практике осуществляется в основном двумя способами: либо предупреждением беременностей с

\footnotetext{
${ }^{1}$ Институт международных исследований семьи после смерти А.А. Попова, сменив несколько руководителей, продолжал научные исследования, но в виду обстоятельств непреодолимой силы фактически прекратил свою деятельность в 2015 г.

${ }^{2}$ Основные результаты этого исследования обсуждались на заседании Демографической секции Московского дома ученых в декабре 1996 г. и частично были публикованы в (Борисов и др. 1997).
} 
помощью контрацепции или стерилизации, либо прерыванием беременности с помощью аборта. Первый путь - цивилизованный, второй - варварский и более опасный для здоровья женщины и ее будущих детей. К сожалению, в нашей стране преобладал второй путь.

В течение всего времени после начала быстрого снижения рождаемости (то есть с 1925 г. до наших дней) Россия является одной из стран с наиболее высоким уровнем абортов в мире. Снижение уровня рождаемости было связано с быстрой индустриализацией, коллективизацией сельскохозяйственного сектора экономики, драматическими изменениями в жизни общества, а также с вовлечением огромного числа женщин в работу в государственном секторе экономики. Все эти изменения привели к снижению ценностей семейной жизни.

Политика Советского государства, направленная на переход от традиционного семейного стиля жизни к новому коллективистскому стилю, привела к множеству негативных изменений - социальных, демографических и санитарных, но государство длительное время даже и не пыталось смягчить эти негативные последствия. Население не получило приемлемых средств контрацепции и необходимой информации о безопасных и эффективных способах предупреждения беременности.

В таких условиях, когда с 1925 г. уровень рождаемости начал снижаться (и снижается до сих пор), его падение стало сопровождаться резким ростом количества абортов. По мнению А.А. Попова, с которым мы согласны, "именно в 20-е годы в России была сформирована особая абортная культура - приспособление и привыкание общества к широкому производству абортов как к основному или даже единственному способу регулирования числа детей в семье" (Попов 1995a, с.115).

Частота абортов в России в течение двух десятилетий, предшествующих началу 1990-х гг., проявляла медленную, но устойчивую тенденцию к снижению. Некоторое повышение числа абортов в расчете на 100 родов в первой половине 90-х гг., думается, является кратковременным отклонением от вышеназванной тенденции, отражением обвального падения рождаемости в эти годы. Абсолютное число абортов и их частота в расчете на 1000 женщин 15-49 лет в эти годы продолжало снижаться (табл. 1).

Таблица 1. Динамика числа абортов в России за 1970-1995 гг.

\begin{tabular}{l|c|c|c}
\hline Годы & Аборты (тысяч) & Аборты на 1000 женщин 15-49 лет & Аборты на 100 родов \\
\hline 1970 & 4838 & 137 & 253 \\
1975 & 4671 & 126 & 221 \\
1980 & 4506 & 123 & 204 \\
1985 & 4454 & 122 & 187 \\
$1990^{*}$ & 4103 & 114 & 206 \\
$1991^{*}$ & 3608 & 100 & 201 \\
$1992^{*}$ & 3437 & 95 & 216 \\
$1993^{*}$ & 3244 & 88 & 235 \\
$1994^{*}$ & 3060 & 82 & 217 \\
$1995^{*}$ & 2766 & 73 & 203 \\
\hline
\end{tabular}

* С 1990 г. - включая мини-аборты, произведенные методом вакуум-аспирации.

Источник: Российский статистический ежегодник / Сборник. М.: Госкомстат, 1996. с. 210.

Хотя динамика уровня абортов выглядела обнадеживающей, уровень абортов оставался самым высоким в мире. В 1994 г. в России в расчете на 100 родов приходилось 
217 абортов, за нами следовала Румыния - 215, затем с большим отрывом Эстония - 158, Украина - 153, с еще большим отрывом Болгария - 127 (1993) и Латвия (1994) - 110. Для сравнения, к примеру, во многих развитых странах с низкой рождаемостью уровень абортов намного ниже. Так, в том же 1994 г. в Швеции число абортов на 100 родов составляло 29, в 1993 г. в Германии - 14, в Великобритании - 24, в Норвегии - 25, в Финляндии - 16, в Испании - 12 (Вишневский 1996, с.55).

Как отмечает Н. Ваганов, зам. министра здравоохранения и медицинской промышленности Российской Федерации, "открыто говорить о контрацептивах, об абортах мы начали лишь два-три года тому назад" (Кухинидзе 1996, с.2). Однако, по его же мнению, переносить в Россию без учета специфики страны западные стандарты контрацептивного поведения не стоит. Гормональная контрацепция в России непопулярна. К ней с недоверием относятся многие гинекологи, особенно закончившие институты 10-15 и более лет тому назад (Мельников 1995).

По мнению главного акушера-гинеколога России В. Серова, сокращение числа абортов понизит доходы врачей, делающих эти операции. Поэтому многие из них выступают против гормональных средств. Боятся гормональной контрацепции и очень многие женщины, запуганные такими врачами. Этих женщин страшит само слово "гормон". Купить гормональные таблетки сейчас можно и без рецепта, но лишь $3,7 \%$ женщин принимают их под контролем врача. Некоторые женщины (число которых никому не известно) используют эти таблетки самостоятельно, без учета медицинских противопоказаний и не всегда соблюдая график приема данных средств, что нередко вызывает осложнения и не всегда гарантирует от зачатия. Сама по себе моральная приемлемость аборта является фактором, противодействующим переходу населения к современным средствам контрацепции: лишь 15\% женщин считают аборт психологической травмой (Мельников 1995).

Однако, с начала 1990-х годов наметились положительные сдвиги в направлении профилактики абортов путем их замещения безопасными, удобными и эффективными средствами контрацепции, прежде всего гормональными и внутриматочными, а также контрацептивной стерилизацией.

В стране с 1991 г. (фактически с 1993 г.) успешно функционирует федеральная Государственная программа "Планирование семьи", параллельно с федеральной программой к 1996 г. 50 российских территорий разработали и осуществляют свои региональные программы на основе местных бюджетов. К участию в финансировании и организации программ планирования семьи привлекаются общественные и частные организации. Создана служба планирования семьи на государственном уровне. В 85 регионах создано более 150 центров по планированию семьи и несколько десятков клиник. Успешно функционирует Ассоциация планирования семьи, имеющая 22 филиала в различных регионах страны.

Удельный вес женщин, использующих современные (оральные и внутриматочные) средства контрацепции, возрос с 22,3\% в 1992 г. до 23,5\% в 1994 г. За тот же период число случаев хирургической стерилизации увеличилось с 9,7 до 13,8 тыс. операций (по данным, приведенным Л.В. Гавриловой, см. также: Попов 1995б, с. 112). Однако, положение с планированием семьи еще очень далеко от удовлетворительного. Как признают сами организаторы службы планирования семьи, замена абортов средствами контрацепции 
происходит очень медленно. Увеличивается число абортов у подростков и первобеременных, что грозит им бесплодием и подрывом здоровья. В стране сохраняется высокий уровень материнской смертности, каждый четвертый из ее случаев связан с последствиями абортов, особенно криминальных (Попов 19956, с. 113).

Несмотря на понимание большой опасности абортов для здоровья женщин и их будущего потомства, медики почти единодушно выступают против перспективы законодательного запрещения производства абортов по желанию женщин. Такое запрещение могло бы только загнать аборты в подполье и сделать их еще более опасными. Наша страна имеет подобный опыт. В 1936 г. аборты были запрещены, что вызвало лишь кратковременную вспышку рождаемости. Позднейшие исследования показали, что в период запрета абортов с 1936 по 1955 гг. они были широко распространены, несмотря на угрозы серьезного уголовного преследования. Подобный же опыт имеет и Румыния, где аборты были запрещены в период с 1966 по 1989 гг.

Однако не все представители власти, очевидно, изучают историю. В связи с резким обострением демографической ситуации в России, время от времени возникают предложения "подправить" положение дел радикальными мерами, в том числе и путем запрещения абортов. В этом же направлении будируют общественное мнение и некоторые общественные организации типа известной организации "Право на жизнь" (Pro Life), а также и представители православной церкви. Поэтому представляется весьма актуальным опрос специалистов самых разных отраслей знания и деятельности по вопросам планирования семьи вообще и абортов в частности.

\section{ЗАДАЧИ ИССЛЕДОВАНИЯ, СОСТАВ ОПРОШЕННЫХ ЭКСПЕРТОВ}

В январе-феврале 1996 г. был проведен экспертный опрос по проблеме абортов в России в форме самозаполнения единого вопросника (см. приложение), распространенного преимущественно при личных контактах с экспертами в Москве и разосланного по почте для экспертов из регионов.

Задачами исследования были:

- выяснение отношения экспертов к проблемам легитимности и моральной приемлемости аборта как средства регулирования деторождения;

- изучение мнений экспертов о моральной оценке искусственного аборта в зависимости от их представлений о сроке начала человеческой жизни и становления личности;

- выявление мнений экспертов о приемлемости действующего законодательства об абортах;

- анализ представлений экспертов о допустимости регулирования людьми своей репродуктивной функцию и о его наиболее приемлемых способах;

- изучение отношения экспертов к аборту в зависимости от их оценки уровня и тенденций рождаемости в России;

- изучение мнений экспертов о деятельности некоторых общественных организаций, выступающих за ограничение или запрещение абортов по желанию женщин; 
- изучение мнений экспертов о возможных последствиях законодательного ограничения права на аборт.

Таблица 2. Профессиональный состав экспертов

\begin{tabular}{l|rr}
\hline Профессия & Человек & $\%$ \\
\hline Демографы & 17 & 19,1 \\
Специалисты по планированию семьи & 13 & 14,6 \\
Медики & 11 & 12,4 \\
Специалисты по гендерным исследованиям & 10 & 11,2 \\
Специалисты по биоэтике & 4 & 4,5 \\
Специалисты по социологии семьи & 9 & 10,1 \\
Юристы & 3 & 3,4 \\
Депутаты Государственной Думы & 11 & 12,4 \\
Представители федеральных и региональных органов исполнительной власти & 9 & 10,1 \\
Священники & 2 \\
\hline
\end{tabular}

Источник: рассчитано и составлено авторами по результатам опроса.

Всего было опрошено 89 экспертов. В их число входили 11 докторов (медицинских, философских, экономических и исторических) и 38 кандидатов (экономических, философских, медицинских, исторических, психологических и географических) наук. В составе экспертов - три академика, 6 профессоров, 15 доцентов и старших научных сотрудников. $85 \%$ экспертов живут и работают в Москве, $15 \%$ - в различных регионах России. Женщин в составе экспертов оказалось 70,5\%, мужчин - 29,5\%.3 Опрошенные эксперты представляют следующие профессиональные группы:

\section{ОТНОШЕНИЕ ЭКСПЕРТОВ К АБОРТУ В ЗАВИСИМОСТИ ОТ ИХ ПРОФЕССИИ}

По мнению подавляющего большинства экспертов, в России абортов "слишком много" (59\% ответивших) или "много" (33\%), что в сумме составляет 92\%. Только 8\% экспертов ответили, что абортов в стране "не много, но и не мало".

Как "слишком много" или "много" единодушно оценили число абортов в стране все демографы, социологи, специалисты по планированию семьи, по биоэтике, юристы и священнослужители. Несколько меньшая доля давших такую оценку среди депутатов Думы (90\%), работников органов исполнительной власти (89\%), медиков $(81,8 \%)$, специалистов по гендерным исследованиям (67\%).

В то же время подавляющее большинство экспертов (93\%) считают искусственное прерывание беременности допустимым. Лишь 7\% из них придерживаются противоположного мнения. Это мнение разделяют $8 \%$ специалистов по планированию семьи, $18 \%$ медиков, $6 \%$ демографов и, естественно, оба священника.

\footnotetext{
${ }^{3}$ Все приведенные в тексте и в таблицах данные опроса экспертов в процентах рассчитаны по отношению к числу экспертов, ответивших на соответствующие вопросы. Во многих случаях процентные отношения исчислены авторами для слишком малочисленных групп респондентов-экспертов, что едва ли следует приветствовать исходя из общих принципов статистического анализа. К интерпретации подобных структурных соотношений нужно подходить с особой осторожностью (прим. редакции).
} 
Те эксперты, которые считают аборты допустимыми, приводят в обоснование своей позиции следующие аргументы:

- Во-первых, 16 экспертов указывают на право женщины распоряжаться своей судьбой. Это право рассматривается ими как одно из основных прав человека.

- Во-вторых, 11 экспертов считают допустимым аборт как средство предотвращения нежеланных рождений.

- В-третьих, 13 экспертов допускают правомерность аборта в случаях, когда существует угроза здоровью женщины или будущего ребенка.

В отдельных анкетах приводятся и другие аргументы в пользу допустимости аборта. Почти все упомянутые в анкетах мотивы допустимости аборта взаимосвязаны и порой их трудно четко разделить на те или иные группы.

Напротив, те немногие эксперты, которые считают аборт недопустимым, либо приравнивают его к убийству, либо указывают на необходимость естественного завершения беременности.

В анкете есть еще один вопрос, ответы на который также позволяют выяснить мнение о допустимости аборта. Он звучал так: "Считаете ли Вы, что каждая беременность должна завершаться родами?". Здесь большинство экспертов также проявили лояльность к аборту.

Однако в этом случае она была несколько слабее выражена, чем в вопросе о допустимости искусственного прерывания беременности. 78\% экспертов ответили здесь "нет", т.е. они не считают, что каждая беременность должна завершаться родами. Альтернативный ответ выбрали 22\%. Чаще всего он встречался у медиков (46\%), социологов семьи (33\%), специалистов по биоэтике $(25 \%)$ и по планированию семьи $(23 \%)$. Такой ответ дали и оба священника.

У сторонников введения ограничений на производство абортов или их запрещения, одним из главных аргументов является то, что аборт - это убийство. С этим согласны $22 \%$ экспертов. Так считают оба священника. Среди других групп экспертов чаще всего такой вариант ответа встречался у специалистов по планированию семьи (39\%), медиков (36\%), работников органов исполнительной власти (33\%). Напротив, среди депутатов Думы, специалистов по гендерным исследованиям и юристов никто не считает аборт убийством. В целом же среди всех экспертов последнего мнения придерживается большинство (56\%).

Часть экспертов (22\%) не смогла ответить на этот основной вопрос ни "да" ни "нет". Они либо затруднились ответить, либо высказали какое-то свое особое мнение. Здесь, например, встречались такие ответы:

- "скорее нет, чем да с учетом нашей действительности",

- "в зависимости от срока беременности",

- "в зависимости от ситуации и причин аборта его можно классифицировать поразному, иногда и как убийство".

По мнению некоторых экспертов, следует трактовать аборт как убийство женщин. Эта точка зрения связана с тем, что значительное число женщин умирает после аборта (Попов 19956, с. 113). 
Когда говорят, что аборт является убийством, то имеют в виду при этом, что человеческая жизнь начинается либо с момента зачатия, либо на ранних сроках беременности. $28 \%$ экспертов считают, что человеческая жизнь начинается непосредственно с момента зачатия. Такого мнения придерживаются оба попавших в число экспертов священника, 54\% специалистов по планированию семьи, 40\% медиков.

$21 \%$ экспертов полагают, что человеческая жизнь начинается в период беременности. Диапазон мнений экспертов о месяце беременности, с которого начинается человеческая жизнь, оказался весьма велик: от второго до седьмого. 1,2\% полагают, что она начинается уже на 2 месяце, 5,9\% - на третьем, 2,4\% - на четвертом, 3,5\% - на пятом, 4,7\% - на шестом, 2,4\% на седьмом и $1,2 \%$ не уточняют, на каком месяце. Таким образом, треть экспертов считают, что жизнь человека начинается либо с момента зачатия, либо в первые 3 месяца беременности - то есть в то время, когда любая женщина в России имеет право на аборт по социальным показаниям.

$37 \%$ экспертов отмечали, что человеческая жизнь начинается только после рождения. Такого мнения придерживаются два из трех опрошенных юристов, 60\% специалистов по гендерным исследованиям, (56\%) социологов семьи, 47\% демографов, 46\% депутатов Думы. У остальных групп экспертов этот вариант ответа встречается значительно реже.

Некоторые из экспертов провели здесь различие между понятием человека как биологического вида и как социального существа. В связи с этим следующим был вопрос: "Можно ли, по Вашему мнению, плод, находящийся в утробе матери, рассматривать как человеческую личность?"

Почти половина (48\%) экспертов считают, что плод - это еще не личность. В ряде групп экспертов такое мнение высказали свыше $60 \%$ опрошенных, в т. ч. среди представителей органов исполнительной власти - 71\%, социологов семьи - 67\%, юристов - 67\%, депутатов Думы - 64\%, демографов - 63\%, специалистов по гендерным исследованиям - $60 \%$. С другой стороны, лишь $15 \%$ специалистов по планированию семьи и $27 \%$ медиков считают, что плод в утробе матери нельзя считать личностью. Среди же священников и специалистов по биоэтике такого варианта ответа не выбрал никто.

$35 \%$ экспертов полагают, что плод становится личностью либо с момента зачатия (19\%), либо во время беременности матери (16\%). Первый из этих вариантов чаще других отмечали священники (100\%), медики (46\%), специалисты по планирования семьи (39\%).

Часть экспертов, высказавших по этому вопросу иное мнение, специально подчеркивали связь становления человеческой личности с процессом ее социализации.

44\% экспертов считают приемлемым действующее у нас законодательство по абортам (среди демографов, медиков, специалистов по планированию семьи, представителей исполнительной власти доля экспертов, давших такой ответ превышает 60\%). Примерно столько же (42\%) экспертов затруднились ответить на этот вопрос. 14\% экспертов не считают действующее законодательство по абортам приемлемым. В число этих экспертов вошли оба священника, половина специалистов по биоэтике, 27\% депутатов Думы, 22\% специалистов по гендерным исследованиям. 
Вот примеры предложений об изменениях в законодательстве:

- "Обеспечить бесплатной контрацепцией подростков, женщин с экстрагенитальными заболеваниями, социально неблагополучных и др." (акушер- гинеколог);

- "Возможность прерывания беременности по желанию до срока 22 недель" (врач);

- "Уточнение обоснованных противопоказаний к деторождению, включая и генетические" (врач-ученый);

- "Аборты должны быть разрешены, бесплатны и качественны" (представитель федеральных органов исполнительной власти);

- "Нужно не "законодательство по абортам", а законодательство по "репродуктивным правам", включающее не только правовые гарантии аборта, но и обеспечивающее государственные усилия для преимущественно безабортного репродуктивного выбора" (специалист по гендерным исследованиям);

- "Аборт должен быть бесплатным, доступным и безопасным" (специалист по гендерным исследованиям);

- "Аборт не должен быть платным" (специалист по гендерным исследованиям);

- "В действующем законодательстве крайне бедно отражены "права плода", защита этих прав. Необходимо компетентное междисциплинарное обсуждение ведомственных (минздравовских) нормативных актов о медицинских и немедицинских (социальных) показаниях к искусственному аборту. Необходим Закон (или отдельные юридические нормы в различных законодательных актах), регулирующий все медицинские вмешательства в репродуктивные процессы человека" (специалист по биоэтике);

- "Отменить аборты по социальным показаниям во втором триместре" (научный сотрудник сектора биоэтики Института человека Российской Академии Наук);

- "Запретить аборты" (священник).

Последнее мнение не имеет широкого распространения, но его сторонники весьма активны. В связи с этим экспертам предлагалось оценить некоторые возможные позитивные и негативные последствия запрещения абортов или ограничения права женщин на прерывание нежелательной беременности.

Подавляющее большинство экспертов считают, что запрещение или ограничение абортов может привести только к негативным последствиям. Однако есть некоторые различия между мнением отдельных групп экспертов по этому вопросу.

\section{Таблица 3. Распределение мнений экспертов о возможных последствиях законодательного ограничения права женщины на аборт (в \%)}

\begin{tabular}{|c|c|c|}
\hline $\begin{array}{l}\text { Согласны ли Вы с мнением, что законодательное ограничение права женщины на аборт } \\
\text { могло бы способствовать: }\end{array}$ & Да & Нет \\
\hline - повышению уровня рождаемости в стране & 12 & 88 \\
\hline - сохранению здоровья женщин & 13 & 87 \\
\hline - криминализации производства абортов & 94 & 6 \\
\hline - повышению духовности общества & 11 & 89 \\
\hline - росту женского бесплодия в результате производства нелегальных абортов & 89 & 11 \\
\hline - ухудшению общего состояния здоровья женщин вследствие нелегальных абортов & 90 & 10 \\
\hline
\end{tabular}

Источник: рассчитано и составлено авторами по результатам опроса. 
44\% опрошенных депутатов Думы, один из трех юристов и оба священника считают, что ограничение права на аборт способствовало бы повышению рождаемости. Треть экспертов из числа депутатов Думы, пятая часть медиков и представителей органов исполнительной власти, оба священника полагают, что ограничение права на аборт благоприятно повлияло бы на сохранение здоровья женщин.

Один из трех юристов и 18\% медиков не согласны с тем, что ограничение права на аборт способствовало бы криминализации производства абортов.

Треть экспертов из числа представителей органов исполнительной власти, оба священника считают, что ограничение права на аборт положительно повлияло бы на состояние духовности общества.

$27 \%$ медиков, и трое из четырех специалистов по биоэтике не согласны с тем, что законодательное ограничение права женщины на аборт способствовало бы росту женского бесплодия в результате нелегальных абортов. Примерно такая же ситуация сложилась и в отношении мнения о возможном ухудшении общего состояния здоровья женщин вследствие нелегальных абортов.

$19 \%$ экспертов считают положительной и полезной деятельность общественных организаций, выступающих за ограничение или запрещение абортов. Мнение об этих организациях среди священников, специалистов по биоэтике и по планированию семьи и медиков более благоприятно, чем среди других групп экспертов.

Наоборот, опасной и вредной деятельность этих организаций считают 45\% экспертов. В первую очередь это юристы, демографы, представители органов исполнительной власти, специалисты по гендерным исследованиям.

Значительная часть экспертов (36\%) не остановила свой выбор ни на одной из двух этих альтернатив в оценке деятельности данных общественных организаций. Они высказали иные мнения, например:

- "деятельность этих организаций может быть полезной только при условии, если абортам будет альтернатива - эффективные средства контрацепции",

- "бесполезная деятельность",

- "любая организация имеет право на свое мнение - и это хорошо",

- "положительной в сфере пропаганды предупреждения нежелательной беременности, сохранения существующей беременности, но не запугивания страшными грехами",

- "деятельность в направлении запрещения абортов вредна, если речь идет о нарушении прав женщин; если же деятельность ставит своей целью пропаганду вреда абортов, информацию о возможностях избежать этой ситуации, то она полезна",

- "в нашем обществе эта деятельность бесполезна",

- "они имеют право выражать свое мнение, если не ущемляют интересов других". 


\section{МНЕНИЯ ЭКСПЕРТОВ РАЗНЫХ ПРОФЕССИЙ О МЕТОДАХ ПРЕДУПРЕЖДЕНИЯ БЕРЕМЕННОСТИ}

Альтернативой аборту, единственно разумным способом существенного сокращения их числа является предупреждение нежелательной беременности. Подавляющее большинство (86\%) экспертов считают его допустимым. Такого мнения придерживаются все без исключения попавшие в число экспертов демографы, специалисты по планированию семьи и по гендерным исследованиям и 91\% депутатов Думы.

$11 \%$ экспертов считают допустимым предупреждение беременности только естественными методами. Чаще всего этот вариант ответа встречался у юристов, специалистов по биоэтике и по социологии семьи, а также у представителей органов исполнительной власти. Только священники полагают, что любые способы предупреждения беременности недопустимы.

96\% экспертов считают, что на смену искусственным абортам, как средству регулирования деторождения, должны прийти высокоэффективные и относительно безопасные противозачаточные средства. Не согласны с этим только оба священника и одна из социологов семьи.

Среди наиболее приемлемых противозачаточных средств или методов чаще всего эксперты отмечали презерватив и гормональные пилюли (в обоих случаях по 64\%) и внутриматочные средства (63\%). Другие средства оказались менее приемлемыми: "рейтинг" у стерилизации составил 38\%, у календарного (ритмического) метода - 38\%, у спермицидов 29\%. Самым непопулярный у экспертов контрацептивный метод - это прерванное сношение, его "рейтинг" составил лишь 15\%. Отметим, что сумма ответов тут намного превышает $100 \%$ поскольку опрашиваемые могли указывать в анкете любое число методов контрацепции.

Некоторые эксперты, не отмечая никаких способов контрацепции из предложенного в анкете списка, указывали на сугубо индивидуальный подход для каждой пары, для каждой женщины. По разным группам экспертов имеет место значительная дифференциация в ответах на вопросы о приемлемости тех или иных способов контрацепции.

У демографов на 1-м месте стоят гормональные препараты (87\%), на 2-м и 3-м презерватив и внутриматочные средства (по 67\%), на 4-м - стерилизация (53\%).

Близкие мнения высказали специалисты по планированию семьи, которые чаще всего отмечали в качестве наиболее приемлемого способа контрацепции гормональные препараты (100\%), на втором месте - презерватив (91\%), на третьем - стерилизация (82\%), на четвертом внутриматочные средства (73\%), на пятом - спермициды (55\%). Данные о священниках не включены в таблицу в виде отдельной колонки поскольку ни один из них не указал ни одного из противозачаточных средств или методов.

Своеобразной выглядит позиция медиков. Часть из них - акушеры и гинекологи, однако они занимаются не столько проблемами планирования семьи, сколько предупреждением и лечением гинекологических заболеваний. Медики, рекомендуя женщинам или брачным парам выбрать то или иное противозачаточное средство или метод, прежде всего обращают внимание на безвредность для здоровья данного вида контрацепции и только потом - на его эффективность, не говоря уже об удобстве применения, тогда как для работников Ассоциации 
и региональных служб планирования семьи на первом месте стоит эффективность контрацепции.

У медиков на первом месте стоит метод ритма (80\%), то есть воздержание от сношений в середине менструального цикла. Разумеется, этот метод совершенно безвреден для здоровья, но он далеко не всегда предотвращает беременность. Специалисты по планированию семьи ставят его только на шестое место и считают наиболее приемлемым лишь в $18 \%$ случаев.

Таблица 4. Доля экспертов, считающих наиболее приемлемыми те или иные средства и методы контрацепции (в \% к числу экспертов данной профессии, указавших хотя бы одно средство или метод)

\begin{tabular}{|c|c|c|c|c|c|c|c|c|c|c|}
\hline & 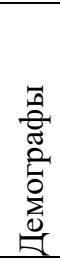 & 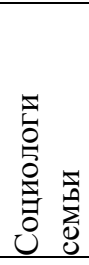 & 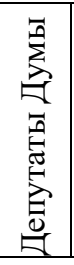 & 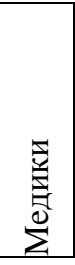 & 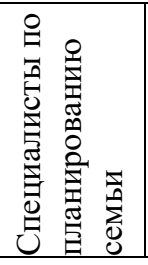 & 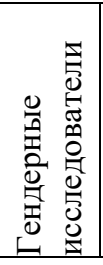 & 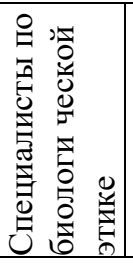 & 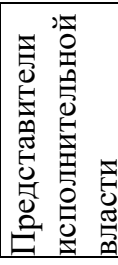 & 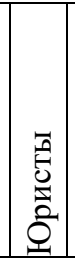 & 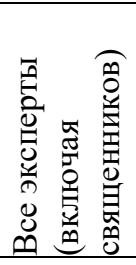 \\
\hline Всего, чел. & 17 & 9 & 11 & 11 & 13 & 10 & 4 & 9 & 3 & 89 \\
\hline $\begin{array}{l}\text { в том числе указали какие- либо методы } \\
\text { из них (\%) }\end{array}$ & 15 & 9 & 8 & 10 & 11 & 7 & 3 & 7 & 3 & 73 \\
\hline Презерватив & 67 & 56 & 50 & 40 & 91 & 86 & 100 & 29 & 100 & 64 \\
\hline Внутриматочные средства & 67 & 67 & 38 & 60 & 73 & 86 & 67 & 57 & 33 & 63 \\
\hline Гормональные средства & 87 & 33 & 50 & 50 & 100 & 86 & 33 & 43 & 33 & 64 \\
\hline Метод ритма & 27 & 44 & 25 & 80 & 18 & 29 & 67 & 29 & 67 & 38 \\
\hline Стерилизация & 53 & 56 & - & 40 & 82 & - & 33 & 14 & - & 38 \\
\hline Спермициды & 27 & 44 & 13 & 30 & 55 & 14 & 33 & 14 & - & 29 \\
\hline Прерванное сношение & 13 & 22 & 13 & 20 & 9 & - & 67 & - & 33 & 15 \\
\hline Прочие & 27 & 22 & 13 & 10 & - & 29 & 67 & 14 & - & 18 \\
\hline
\end{tabular}

Источник: рассчитано и составлено авторами по результатам опроса.

На второе место медики ставят внутриматочные средства (60\%), на третье гормональные препараты (50\%). Половина из медиков либо негативно относятся к этим высокоэффективным препаратам, либо не считают их средством предупреждения беременности. Очевидно, у этих медиков до сих пор сохранилось мнение о вредности данного вида контрацепции для здоровья женщин. Между тем, все без исключения работники Ассоциации по планированию семьи и ее региональных служб, ответившие на данный вопрос, считают наиболее приемлемой гормональную контрацепцию.

Социологи семьи наиболее приемлемым способом контрацепции считают внутриматочные средства (67\%), далее идут презерватив и стерилизация (по 56\%), ритмический метод и спермициды (по 44\%) и только на шестом месте - гормональные препараты $(33 \%)$.

Депутаты Думы чаще всего отмечали в этом вопросе презерватив и гормональные препараты (по 50\%), внутриматочные средства (38\%). Интересно, что никто из этой группы экспертов не отметил в качестве приемлемой стерилизацию.

По мнению представителей органов исполнительной власти наиболее приемлемы внутриматочные средства (57\%), далее идут гормональные препараты (43\%), презерватив и ритмический метод (по 29\%). Никто из этой группы экспертов не отметил прерывание полового акта. 
У специалистов по гендерным исследованиям на первом-третьем местах стоят презерватив, внутриматочные средства и гормональные препараты (по 86\%). Ни одна из представительниц этой группы экспертов не отметила стерилизации и прерывания полового акта.

Специалисты по биоэтике чаще всего отмечали презерватив (100\%), внутриматочные средства, ритмический метод и прерывание полового акта (по 67\%).

У юристов на первом месте тоже стоит презерватив (100\%), далее идет ритмический метод $(66,7 \%)$. Никто из них не отметил стерилизации и спермицидов.

\section{ВЛИЯНИЕ ДЕМОГРАФИЧЕСКОГО И МОРАЛЬНОГО ФАКТОРОВ НА ОТНОШЕНИЕ К АБОРТАМ}

Мы пытались оценить, какие факторы являются более значимыми в формировании негативного отношения к абортам. При этом сравнивались демографические факторы и моральные факторы. Под демографическими факторами имелись в виду отношение эксперта к проблеме рождаемости. Если эксперт высказывал мнение, что существующие тенденции рождаемости угрожают нормальному воспроизводству населения России и при этом высказывает отрицательное отношение к абортам, есть основания полагать, что в основе этого отношения лежат и демографические мотивы (хотя они могут сочетаться с другими мотивами).

Подавляющее большинство экспертов - 67 чел. или 76\% из ответивших, считают, что современные тенденции рождаемости в России являются угрожающими нормальному воспроизводству населения, лишь 8 человек (9\%) признают эти тенденции вполне нормальными. Еще 13 чел. (15\%) высказали иные мнения и только один из экспертов не ответил на данный вопрос. Среди экспертов, обеспокоенных проблемой воспроизводства населения, негативное отношение к аборту встречается чаще, чем среди тех, кто считает, что с воспроизводством все обстоит нормально. Однако даже и в первой группе противники абортов составляют явное меньшинство.

Негативное отношение к аборту в данном случае определялось по ответам на шесть вопросов:

1. Ответ "да" на вопрос: "Некоторые люди считают, что аборт - это убийство. Вы согласны с таким мнением?" В первой группе экспертов ответил "да" каждый четвертый $(24 \%)$, во второй - лишь один из 8 (13\%).

2. Ответ "да" на вопрос: "Считаете ли Вы, что каждая беременность должна завершаться родами?" В первой группе экспертов согласились с этим суждением также $24 \%$, во второй - таких вообще не оказалось.

3. Ответ "нет" на вопрос: "На Ваш взгляд, допустимо ли искусственное прерывание беременности?" Во второй группе тоже не было ни одного такого ответа, но и в первой их оказалось ничтожное меньшинство - всего $9 \%$.

4. Ответ "нет" на вопрос: "Считаете ли Вы приемлемым действующее у нас законодательство по абортам?". Ситуация, сходная с ответом на предыдущий вопрос. Во второй группе нет ни одного человека, который считает это законодательство 
неприемлемым. В первой группе такие люди есть, но их немного - только 15\%. Следует иметь в виду, что те, кто относится отрицательно к ныне действующим законам, согласно которым любая женщина имеет право прервать беременность сроком до 12 недель (а в ряде случаев - и на более поздних сроках), чаще всего считают эти законы слишком либеральными.

5. Согласие с утверждением, что законодательное ограничение права женщины на аборт могло бы способствовать повышению уровня рождаемости в стране. Так же, как и на предыдущий вопрос ответили "да" 15\% экспертов из первой группы, а во второй группе таких вообще не оказалось.

6. Одобрительное отношение к деятельности общественных организаций, выступающих за ограничение или запрещение абортов по желанию женщин. 22\% экспертов из первой группы и 13\% из второй ответили: "Считаю их деятельность положительной и полезной".

Таким образом, ответы на четыре из данных шести вопросов показывают, что негативное отношение к абортам вообще не встречается у экспертов, которые считают, что нынешние тенденции рождаемости не оказывают негативного влияния на воспроизводство населения. Судя по ответам на остальные два вопроса, отрицательно относится к абортам только один из восьми экспертов, входящих в эту маленькую группу, то есть 13\%.

Среди экспертов, обеспокоенных обострением проблемы воспроизводства населения из-за низкой рождаемости, негативное отношение к аборту встречается чаще, чем в первой группе, но отнюдь не является преобладающим. Максимальная частота антиабортных установок даже в этой группе составляет лишь 24\% (по ответам на вопросы о том является ли аборт убийством и должна ли каждая беременность завершаться родами). Лишь 15\% экспертов из этой группы считают, что законодательное ограничение права женщин на аборт способствовало бы повышению рождаемости. Между тем, это единственный чисто "демографический" мотив отрицательного отношения к аборту. И даже среди тех экспертов, которые обеспокоены проблемой воспроизводства населения, он встречается реже, чем негативное мнение об аборте, связанное с моральными соображениями.

Главным индикатором этих моральных соображений являются ответы на вопрос: "Можно ли, по Вашему мнению, плод, находящийся в утробе матери, рассматривать как человеческую личность?" Если эксперт отвечал, что плод является личностью начиная с момента зачатия или не позднее, чем с третьего месяца беременности (всего таких ответов было 20), то можно было ожидать что такой эксперт будет противником абортов по чисто моральным мотивам. И действительно, по всем шести вопросам эти эксперты (группа 3) дают более высокий процент "антиабортных" ответов, чем эксперты, обеспокоенные воспроизводством населения (группа 1).

Так, эксперты из группы 1 считают аборт убийством в 24\% случаев, а эксперты из группы 3 в 55\% случаев. Почти половина последних (45\%) все-таки не признает прерывание беременности убийством, главным образом потому, что считает аборт вынужденным поступком в условиях низкой контрацептивной культуры населения. Мнение о том, что каждая беременность должна завершаться родами, также разделяют $24 \%$ экспертов в группе 1 и 53\% в группе 3. Процент экспертов, считающих, что законодательное ограничение права 
женщин на аборт повысит рождаемость, также выше среди тех, кто осуждает аборт по моральным соображениям (18\%), чем среди тех, кто обеспокоен проблемой воспроизводства населения (15\%), хотя эта небольшая разница, скорее всего, носит случайный характер.

Таблица 5. Связь между оценкой демографической ситуации, моральными воззрениями экспертов и их отношением к абортам

\begin{tabular}{|c|c|c|c|c|c|c|}
\hline \multirow[b]{2}{*}{$\begin{array}{l}\text { Группа } \\
\text { экспертов }\end{array}$} & \multicolumn{6}{|c|}{ Доля (\%) экспертов, считающих, что: } \\
\hline & $\begin{array}{c}\text { Аборт - } \\
\text { это } \\
\text { убийство }\end{array}$ & $\begin{array}{c}\text { Каждая } \\
\text { беременность } \\
\text { должна } \\
\text { завершаться } \\
\text { родами }\end{array}$ & $\begin{array}{c}\text { Искусственное } \\
\text { прерывание } \\
\text { беременности } \\
\text { недопустимо }\end{array}$ & $\begin{array}{c}\text { Существующее } \\
\text { законодательство } \\
\text { об абортах } \\
\text { неприемлемо }\end{array}$ & \begin{tabular}{|c|} 
Ограничение \\
права на аборт \\
повысит \\
рождаемость
\end{tabular} & $\begin{array}{c}\text { Деятельность } \\
\text { "анти- } \\
\text { абортных" } \\
\text { организаций } \\
\text { является } \\
\text { полезной }\end{array}$ \\
\hline
\end{tabular}

(1) “угрожающие Оиенка тенденичй рождаемости: воспроизводству

населения"

(2) “нормальные"

Разница между

группами (1) и (2)

(3) с зачатия или

не позже 3-его

месяца

24

24

9

15

13

$+11$

55

53

21

20

20

2

10

$+10$

$+19$

$+33$

Разница между

группами (3) и (4)

Источник: рассчитано и составлено авторами по результатам опроса.

С другой стороны, среди экспертов, не признающих плод в первом триместре беременности человеческой личностью $13 \%$ все-таки полагают, что введение ограничений на аборты повысит рождаемость, а среди тех экспертов, которых проблема рождаемости не беспокоит, таких нет вообще.

Влияние демографического фактора на формирование негативного отношения к аборту определялось по разнице между процентами ответивших на соответствующие вопросы среди обеспокоенных проблемой воспроизводства населения (группа 1, состоит из 67 чел.) и считающих, что с воспроизводством (в аспекте рождаемости) все нормально (группа 2, состоит из 8 чел.).

Влияние морального фактора определялось соответственно по разнице между ответами тех, кто считает, что плод становится личностью с момента зачатия или не позже третьего месяца беременности и теми, кто относит становление личности на более поздние сроки беременности или после рождения. Мнение о признании плода личностью на ранних сроках беременности превалирует во всех группах экспертов, но особенно значительно, что ожидаемо, среди тех, кто считает аборт убийством и тех, кто считают полезной деятельность организаций, поддерживающих Pro-life ценности. 
Фактор возраста не оказывает заметного влияния на формирование у экспертов негативного отношения к абортам (индикаторами этого отношения считались ответы на те же вопросы, что и в таблице 5). Это влияние проявляется только в двух случаях:

1. Чем моложе эксперты, тем чаще они считают, что каждая беременность должна завершаться родами: в возрасте до 40 лет так полагают 29\%, в 40-49 лет - 23\%, а после 50 лет - только 19\%. Однако, несмотря на эту тенденцию, во всех возрастах подавляющее большинство экспертов (свыше 70\%) данную точку зрения не разделяют.

2. Группа 40-49 лет довольно резко выделяется своей склонностью расценивать аборт как убийство: так считают 30\% экспертов данного возраста по сравнению с 13\% среди более молодых и с 19\% среди более старших экспертов.

Однако, вопреки всякой логике, именно в этой возрастной группе, реже всего (лишь в $6 \%$ случаев по сравнению с $17 \%$ в группе до 40 лет и с $19 \%$ в группе старше 50 лет) высказываются мнения о неприемлемости действующего в России законодательства об абортах, которое практически всем женщинам разрешает совершать эти "убийства". Такое противоречие объясняется скорее всего небольшой численностью групп: экспертов моложе 40 лет всего - 24, от 40 до 49 лет - 33, старше 50 лет - 26 человек. Шесть экспертов не указали в анкете свой возраст.

Пол экспертов влияет на их отношение к абортам более заметно, чем возраст. Это связано с самим характером проблемы. Мужчины реже, чем женщины, признают аборт убийством (15\% против 25\%), но в три раза чаще, чем женщины (24\% против $8 \%$ ) считают нынешние законы об аборте неприемлемыми. Кроме того, мужчины в 4 с лишним раза чаще, чем женщины (25\% против 6\%) утверждают, что ограничение права женщин на аборт приведет к повышению рождаемости (во что среди самих женщин почти никто не верит). Наконец, почти треть мужчин-экспертов (32\%) положительно относится к организациям, выступающим за запрещение абортов или введение ограничений на их производство. Среди экспертов-женщин такое одобрение высказали только 14\%.

Складывается впечатление, что большинство экспертов-женщин, которые осуждают аборты по моральным соображениям и даже приравнивают их к убийству, тем не менее признают, что каждая женщина вправе брать такой грех на свою душу, а государство или общественные организации не должны ей в этом препятствовать.

Интересно, что данные опроса экспертов показали те же самые закономерности, что и результаты опроса общественного мнения, проведенного ВЦИОМ (Всероссийским центром изучения общественного мнения) в 1994 г. Согласно данным этого исследования, 88\% опрошенных женщин высказались за законное право женщин прерывать беременность, если они по каким-либо причинам не хотят иметь ребенка. Среди мужчин сторонников этого мнения оказалось несколько меньше, но они также составляют подавляющее большинство $73 \%$. Какой-либо существенной связи между возрастом респондентов и их отношением к аборту обнаружено не было (Бодрова 1995, с.26). 


\section{ЗАКЛЮЧЕНИЕ}

Проведенное исследование позволяет сделать ряд важных выводов:

1. Подавляющее большинство опрошенных экспертов придерживаются мнения о безусловном праве женщин решать судьбу своей беременности. Эта позиция разделяется большинством экспертов, независимо от их взглядов на моральные аспекты проблем абортов и контрацепции.

2. Большинство экспертов выступают безусловными противниками любого законодательного запрета абортов или ограничения права женщин на прерывание беременности. По их мнению, такой запрет мог бы иметь только отрицательные последствия в виде резкого увеличения числа криминальных абортов, и, как результат последнего - ухудшения состояния здоровья женского населения.

3. Значительная (но меньшая) часть экспертов не одобряет абортов (в основном по моральным соображениям), но и среди них большинство считает допустимым искусственное прерывание беременности по желанию женщины. Многие из таких экспертов мотивировали свою позицию тем, что женщины вынуждены прибегать к абортам из-за низкой эффективности и неудобства в применении наиболее распространенных в России средств и методов контрацепции. Современные (внутриматочные и гормональные) средства контрацепции до сих пор имеют в стране весьма малое распространение.

4. Хотя более трех четвертей экспертов считает, что существующие в России тенденции рождаемости угрожают нормальному воспроизводству населения, тем не менее они, как правило, не считают целесообразным запрещение абортов или ограничение права женщин на прерывание беременности. Лишь $15 \%$ экспертов из данной группы полагают, что подобные меры могли бы способствовать повышению рождаемости.

5. Несмотря на крайне тяжелую демографическую ситуацию в стране, у тех экспертов, кто выразил негативное отношение к абортам, это отношение мотивируется в основном моральными, а не популяционистскими соображениями.

6. Отношение экспертов к абортам почти не зависит от их возраста. Пока нет оснований считать, что смена поколений сама по себе приведет к изменению моральной оценки аборта даже среди специалистов, не говоря уже о массах населения.

7. Мужчины-эксперты гораздо реже, чем женщины признают аборт аморальным поступком, но значительно чаще делают из этого признания вывод о необходимости борьбы с абортами и верят в то, что эта борьба даст позитивные результаты. Впрочем, и среди мужчин-экспертов такого мнения придерживается лишь меньшинство - менее одной трети. 


\section{ЛИТЕРАТУРА}

Бодрова В.В. (1995). Сексуальная мораль и репродуктивное поведение населения. Экономические и социальные перемены: мониторинг общественного мнения. Информационный бюллетень, 3 (май-июнь), 25-27.

Борисов В., Синельников А., Архангельский В. (1997). Аборты и планирование семьи в России: правовые и нравственные аспекты (опрос экспертов). Bonpocы статистики, 3, 75-81.

Вишневский А.Г. (ред.) (1996). Население России 1995. Третий ежегодный демографический доклад. М.: Центр демографии и экологии человека.

Вишневский А.Г., Денисов Б.П., Сакевич В.И. (2017). Контрацептивная революция в России. Демографическое обозрение, 4(1), 6-34. DOI: https://doi.org/10.17323/demreview.v4i1.6986

Кочергина Е. (2017). Как общество отвечает на неотрадиционалистскую политику государства (на примере отношения к абортам). Вестник общественного мнения, 1-2 (124), 141-151.

Кухианидзе С. (1996). Это должен знать каждый. Московская правда, 20 февраля.

Мельников А. (1995). Проблема. Независимая газета, 19 октября.

Попов А.А. (1995а). Аборты в России. Человек, 1, 113-119.

Попов А.А. (1995б) Демонополизация политики планирования семьи в России. Семья в России, 3-4, 109-119.

Российский статистический ежегодник / Сборник. М.: Госкомстат, 1996.

Сакевич В. И., Денисов Б. П. (2019). Репродуктивное здоровье населения и проблема абортов в России: новейшие тенденции. Сочиологические исследования, 11, 140-151. DOI: $10.31857 / \mathrm{S} 013216250007457-5$

Тёмкина А.А. (2013). Советы гинекологов о контрацепции и планировании беременности в контексте современной биополитики в России. Журнал исследований социиальной политики, 11(1), 7-24. URL: https://jsps.hse.ru/article/view/3445

Denisov B.P, Sakevich V.I, Jasilioniene A. (2012). Divergent Trends in Abortion and Birth Control Practices in Belarus, Russia and Ukraine. PLoS ONE 7(11): e49986. DOI: 10.1371/journal.pone.0049986

Philipov D., Andreev E., Kharkova T., Shkolnikov V. (2004). Induced Abortion in Russia: Recent Trends and Under-Reporting in Surveys. European Journal of Population, 20: 95-117. DOI: https://doi.org/10.1023/B:EUJP.0000034499.24658.7a

Troitskaia I., Avdeev A., Badurashvili I., Kapanadze E., Tretjakova V. (2009). Étude comparative des pratiques contraceptives: France, Géorgie, Lituanie et Russie. Revue d'études comparatives Est-Ouest, 40, 3-4, Septembre-Décembre, 241-272. DOI : 10.4074/S0338059909003088 


\title{
LEGAL AND MORAL ASPECTS OF INDUCED ABORTION AND FAMILY PLANNING IN RUSSIA: RESULTS OF AN EXPERT SURVEY CONDUCTED IN 1996
}

\author{
VLADIMIR BORISOV, ALEXADER SINELNIKOV, VLADIMIR ARKHANGELSKY
}

\begin{abstract}
The article presents the results of a survey of experts conducted in January-February 1996 in order to identify the opinions of experts on fundamental issues related to birth control in Russia. This study was part of the research project "Family Planning and Public Health Policy in Russia: The Transition from Abortion to Contraception in a Changing Society", carried out by the Transnational Family Research Institute (Moscow) in 1995-1997. In total, 89 experts were interviewed, representing academic communities in various fields of knowledge (geography, demography, history, psychology, medicine, philosophy, and economics), public health administrators and practitioners, State Duma deputies, representatives of federal and regional executive authorities and priests. The survey program covered the issues of the legitimacy and moral acceptability of abortion, an assessment of the current legislation on induced abortion, an assessment of people's acceptance of the regulation of reproductive function and of the most acceptable methods of birth control in the context of fertility trends in the country, an assessment of the activities of NGOs advocating the limitation and prohibition of voluntary abortion and the possible consequences of changes in legislation in relation to abortion and family planning. The overwhelming majority of the experts supported the unconditional right of women to decide the fate of their pregnancy. According to experts, a legislative ban on abortion and restricting the right of women to terminate pregnancy if they wish would not solve the problem of low fertility, and could only have negative consequences in terms of increasing the level of criminality in the country and worsening the health of many women. A quarter of a century later, the questions raised in the study of the mid-1990s remain relevant.
\end{abstract}

Key words: expert survey, fertility, induced abortions, family planning, contraception, reproductive health, legislation on abortion.

VLADIMIR BORISOV, DIED IN 2005. AT THE TIME OF THIS WRITING, HE WORKED AT THE FACULTY OF SOCIOLOGY, LOMONOSOV Moscow State University AND AT THE State Pedagogical UNiversity.

Alexander Sinelnikov (sinalexander@yandex.ru), Lomonosov Moscow State University, Russia.

Vladimir ARKhangelsky (archangelsky@yandex.ru), Lomonosov Moscow STATE University, RusSia.

DATE RECEIVED : JUNE 2021.

\section{REFERENCES}

Bodrova V.V. (1995). Seksual'naya moral' i reproduktivnoe povedenie naseleniya [Sexual Moral and Reproductive Behavior of the Population]. Ekonomicheskie $i$ sotsial'nye peremeny: monitoring obshchestvennogo mneniya. Informatsionnyy byulleten' [Economic and Social Change: the Monitoring of Public Opinion], 3: 25-27. (In Russ.)

Borisov V., Sinelnikov A., Arkhangelsky V. (1997). Aborty i planirovanie sem'i v Rossii: pravovye i nravstvennye aspekty (opros ekspertov) [Abortion and Family Planning in Russia: Legal and moral aspects (expert survey)]. Voprosy statistiki [Statistical issues], 3: 75-81. (In Russ.)

Denisov B.P, Sakevich V.I, Jasilioniene A. (2012). Divergent Trends in Abortion and Birth Control Practices in Belarus, Russia and Ukraine. PLoS ONE 7(11): e49986. DOI: 10.1371/journal.pone.0049986 
Kochergina E. (2017). Kak obshchestvo otvechaet na neotraditsionalistskuyu politiku gosudarstva (na primere otnosheniya $\mathrm{k}$ abortam) [How society responds to the neotraditionalist policy of the state (on the example of the attitude to abortion)]. Vestnik obshchestvennogo mneniya [Bulletin of Public Opinion], 1-2 (124): 141-151. (In Russ.)

Kukhianidze S. (1996). Eto dolzhen znat' kazhdyy [Everyone should know this]. Moskovskaya Pravda, February 20. (In Russ.)

Melnikov A. (1995). Problema [The Problem]. Nezavisimaya gazeta, October 19. (In Russ.)

Philipov D., Andreev E., Kharkova T., Shkolnikov V. (2004). Induced Abortion in Russia: Recent Trends and Under-Reporting in Surveys. European Journal of Population, 20: 95-117. DOI: https://doi.org/10.1023/B:EUJP.0000034499.24658.7a

Popov A.A. (1995a). Aborty v Rossii [Abortions in Russia]. Chelovek [Human Being], 1: 113-119. (In Russ.)

Popov A.A. (1995b). Demonopolizatsiya politiki planirovaniya sem'i v Rossii [Demonopolization of family planning policy in Russia]. Sem'ya v Rossii [Family in Russia], 3-4: 109-119. (In Russ.)

Rossiyskiy statisticheskiy ezhegodnik / Sbornik [Russian Statistical Yearbook]. M: Goskomstat, 1996. (In Russ.)

Sakevich V.I., Denisov B.P. (2019). Reproduktivnoe zdorov'e naseleniya i problema abortov v Rossii: noveyshie tendentsii [The Latest Trends in Reproductive Health and the Problem of Abortion in Russia]. Sotsiologicheskie issledovaniya [Sociological Studies], 11: 140-151. (In Russ.) DOI: 10.31857/S013216250007457-5

Temkina A.A. (2013). Sovety ginekologov o kontratseptsii i planirovanii beremennosti v kontekste sovremennoy biopolitiki v Rossii [Gynecologists' Advices on Contraception and Pregnancy Planning in the Context of Contemporary Biopolitcs in Russia]. The Journal of Social Policy Studies, 11(1): 7-24. (In Russ.) Retrieved from https://jsps.hse.ru/article/view/3445

Troitskaia I., Avdeev A., Badurashvili I., Kapanadze E., Tretjakova V. (2009). Étude comparative des pratiques contraceptives: France, Géorgie, Lituanie et Russie. Revue d'études comparatives Est-Ouest, 40, 3-4, Septembre-Décembre, 241-272. DOI : 10.4074/S0338059909003088

Vishnevsky A.G. (ed.) (1996). Naselenie Rossii 1995 [Population of Russia]. Tretiy ezhegodnyy demograficheskiy doklad. M.: Tsentr demografii i ekologii cheloveka. (In Russ.)

Vishnevsky A.G., Sakevich V.I., Denisov B.P. (2017). The contraceptive revolution in Russia. Demograficheskoe obozrenie [Demographic Review], English selection 2017: 86-108. DOI: https://doi.org/10.17323/demreview.v4i5.8570 


\section{ПРИЛОЖЕНИЕ}

\section{Вопросник для эксперта}

Уважаемый(ая) коллега!

Институт международных исследований семьи (Москва) проводит опрос мнений экспертов по проблеме планирования семьи в нашей стране. Просим Вас ответить на ряд вопросов. Без Вашего согласия Ваше имя не будет использовано ни при каких обстоятельствах.

1. Считаете ли Вы, что современные тенденции рождаемости в России являются:

1. Угрожающими нормальному воспроизводству населения

2. Вполне нормальными

3. Иное мнение:

2. По Вашему мнению, современный уровень рождаемости в России можно оценить как:

1. Чрезмерно высокий

2. Оптимальный

3. Чрезмерно низкий

4. Иное мнение:

3. Считаете ли Вы, что уровень рождаемости в России в ближайшее время будет:

1. Снижаться

2. Повышаться

3. Оставаться почти неизменным

4. Считаете ли Вы, что число детей в семье должно прежде всего отвечать интересам:

1. Общества

2. Семьи

3. Иное мнение:

5. На Ваш взгляд, абортов в России:

1. Слишком много

2. Много

3. Не много, но и не мало

4. Мало

6. Некоторые люди считают, что аборт - это убийство. Вы согласны с таким мнением?

1. Да

2. Нет

3. Иное мнение:

7. Считаете ли Вы, что человеческая жизнь начинается:

1. Непосредственно с момента зачатия

2. С месяца беременности

3. После рождения

4. Иное мнение:

8. Можно ли, по Вашему мнению, плод, находящийся в утробе матери, рассматривать как человеческую личность?

1. Нельзя

2. Можно, причем непосредственно с момента зачатия

3. Можно, но начиная с месяца беременности

4. Иное мнение: 
9. Считаете ли Вы, что каждая беременность должна завершаться родами?

1. Да

2. Да, но только естественными методами

3. Нет

10. Если "да", то почему?

11. На Ваш взгляд, допустимо ли предупреждение беременности?

1. Да

2. Нет

12. Почему Вы так считаете?

13. На Ваш взгляд, допустимо ли искусственное прерывание беременности?

1. Да

2. Нет

14. Почему Вы так считаете?

15. Считаете ли Вы приемлемым действующее у нас законодательство по абортам?

1. Да

2. Нет

3. Трудно сказать

16. Если «нет», то какие изменения, с Вашей точки зрения, следует в него внести?

17-22. Согласны ли Вы с мнением, что законодательное ограничение права женщины на аборт могло бы способствовать:

17. Повышению уровня рождаемости в стране

Да Нет

18. Сохранению здоровья женщин

12

19. Криминализации производства абортов

12

20. Повышению духовности общества

12

21. Росту женского бесплодия в результате производства нелегальных абортов

12

22. Ухудшению общего состояния здоровья женщин вследствие нелегальных абортов

23. Считаете ли Вы, что на смену искусственным абортам, как средству регулирования деторождения, должны прийти высокоэффективные и относительно безопасные противозачаточные средства?

1. Да

2. Нет

24. Если “да”, то какие противозачаточные средства или методы Вы считаете наиболее приемлемыми (по любым соображениям)

1. Презерватив

2. Внутриматочные средства

3. Гормональные препараты

4. Стерилизация

5. Периодическое воздержание (ритмический метод)

6. Спермициды (медицинские средства токсического воздействия на жизнеспособность сперматозоидов)

7. Прерывание полового акта

8. Другие способы (какие?) 
25. Как Вы относитесь к деятельности общественных организаций, выступающих за ограничение или запрещение абортов по желанию женщин?

1. Считаю их деятельность положительной и полезной

2. Считаю их деятельность опасной и вредной

3. Иное мнение:

26. Если Вам представляются важными какие-то другие аспекты затронутой в анкете проблемы, то Вы можете высказать свое мнение по ним здесь. На Ваш взгляд, допустимо ли предупреждение беременности?

А теперь расскажите немного о себе:

27. Ваш пол: 1 - мужской 2 - женский

28. Год и месяц рождения

29. Профессия

30. Место работы

31. Должность

32. Ученая степень (если есть)

33. Ученое звание (если есть)

Если хотите, укажите фамилию и инициалы. 